\title{
Trigger Warnings: Sex, Lies and Social Justice Utopia on Tumblr
}

\author{
LENORE BELL - University of St. Andrews
}

\begin{abstract}
In the spring of 2012, a major scandal rocked the queer social justice community on Tumblr. One of its most popular bloggers and activists, a 22 -year-old transman named Ira Gray suddenly faced by a deluge of sexual assault allegations from multiple people via Tumblr. Despite the queer social justice community's pride in being open and accepting, many of its practices are rigid, pedantic and counterproductive. The rise and fall of Ira Gray's celebrity status has highlighted how truly divided this online community can be. Sexuality and gender identity were not the only lines of contention; mental illness, race, class and trauma played dominant roles in the discussion. The very fact that the accusers had stayed silent for so long is telling. Through analysing the tumblr posts of the accused, accusers and other commentators/spectators, one can see how mental illness, privilege and sexuality are negotiated in this small yet global community. For many queer social justice tumblr bloggers, graphically detailed posts about their experience of sexual trauma lie side-by-side with explicit nude phone camera portraits of the blogger tagged as "self-care." I argue that the ethos created by this corner of the internet does not provide a queer oasis for the user away from an overbearing, hetero-normative world. Instead, it introduces a complicated set of rules and mores that presents new complications. The combination of naked exposure and online depersonalisation can prove toxic.
\end{abstract}

KEYWORDS: Tumblr, queer identity, activism, identity politics, groupthink,

\section{Introduction: The Power of Spyware}

In the early 1990s, there was a popular children's show on the Public Broadcasting Service called Ghostwriter. It was about a group of Brooklyn-based school children who solved crimes. One of the episodes, "Who is Max Mouse?" centered around a rash of computer hackings going on in their school. A prime suspect is the school's newspaper editor, a surly smart-aleck named Erica. (Notably, she is played by a young Julia Stiles.) Erica fancies herself a cyberpunk and has read Neuromancer by William Gibson, an urtext for the early web savvy elite. When asked where she learned about hackers, she points to a computer and dreamily intones: "In there. It's a world where you're judged by what you say and think. Not by what you look like. A world where curiosity and an imagination equals power." 1

\footnotetext{
1 "Max Mouse Part 1 (2of3)." Youtube. http://www.youtube.com/watch?v=gRzPWCJqEVY
} 
Advances in new technology inspire promises of a more egalitarian life for mankind. However, these visions often overstep the practical constraints of human nature. In the case of the internet, it is often assumed that the complex problems of the physical world can be subverted and overcome in the virtual world. A person's appearance, location, and station in the physical world can be effectively cancelled by the great leveller known as the internet. The virtual world is often tacitly viewed as a tabula rasa. Even the current generation of savvy internet users are not immune. Their parents' generation was similarly drawn to the promise of a clean new start. In 1969, a commune called Synergia ${ }^{2}$ was established in New Mexican desert. It was one of many of the utopian communes set up at the time, in response to the many concurrent social upheavals in America. Synergia was based on the teachings of Buckminster Fuller, the inventor of the biosphere. One of the founding premises of Synergia was that life can be enhanced through communal living and total honesty. Members would hold long sessions where they would tell each other how they honestly felt about each other.

At first glance this appears to be typical hippie logic, but it has a startlingly mechanical basis underlying it. Buckminster Fuller believed that nature self-regulated through a system of constant and continuous feedback loops, which kept it stable. He believed that this idea could be applied to humans, as well as computers. This commune was practicing a theory which worked in a vacuum. However, it failed to take into account human nature. Eventually the commune failed due to the fact that the dominant personalities in the group hijacked the feedback sessions for their own use. There was no mechanism to counter this, because Synergia wanted to be free of anything which resembled politics. As a result, anxiety and silent fear ran high in the community. Interestingly enough, one former member described this tension as "spyware": "It was just running the background. You knew it was there."There are striking parallels to be found between Synergia's breakdown and an event which occurred in a corner of the queer social justice community on Tumblr in the summer of 2012. The latter community also believes that they are also a space for truth and openness. Like their predecessors at Synergia, they painstakingly tried to create a haven, a safe space for the group. It was this attempt to preserve this safety which also contributed to its integrity being severely undermined.

The Ira Gray incident which I will describe provides an intriguing study of what happens when a dominating figure infiltrates a virtual space with an egalitarian mandate. Despite the emphasis on openness and transparency in the queer social justice community, Ira Gray's posts managed to gain a reliable status. This aura of infallibility around his name was akin to something associated with more conservative figures, such as pastors or respected politicians. Directly criticizing Ira himself became impossible. Despite his statements to the contrary, Ira was not in the community to learn or listen. He was there to broadcast his own opinions and expected them to be received positively, without question. In order to explain his rise and fall, one has to understand the community in which it took place. First, I will describe the queer Tumblr community and its attempts construct a safe space. Then, I will describe how those devices to create a safe space ultimately backfire. I describe the world outside of the internet as "the real world", "reality" or "the physical world."

\footnotetext{
${ }^{2}$ The Use and Abuse of Vegetational Concepts: Ecology, Technology, and Society-All Watched Over by Machines of Loving Grace. Dir. Adam Curtis. N.p., n.d. Web.
} 


\section{Why Tumblr?}

Tumblr, the social networking platform, was launched in February of 2007. It vies for marketspace alongside the likes of Facebook and Twitter. However, Tumblr offers something very different than it's competitors. As a Wired article about the site puts it:

If Facebook is the social network for online identification and authentication, and Twitter is for communication, Tumblr fulfils a different role: self-expression. Users can upload seven types of media -- text, photos, quotes, links, dialogue, audio, video -- from one button on their dashboard and push it to their public-facing tumblelog... Tumblr is extremely easy to use as a free-form blogging platform, but has also developed into its own social network. Users follow other tumblelogs, whose content appears in their dashboards... hitting the "reblog" button publishes that post to their own blogs, a feature Tumblr put out two years before Twitter introduced its own retweet button. "The social network that emerges out of Tumblr is interesting because it's driven by content, not by the social graph that these other networks are building around," says John Maloney, the company's president. And that content spreads quickly: on average, a Tumblr post gets reblogged nine times. ${ }^{3}$

Due to its unique format Tumblr is more removed from the user's real-life social networks than Facebook, as Facebook "friendships" are more likely to be established after a real life connection has been made. Tumblr is also more more pleasurable to scan as a backlog than Twitter, which is less visually engaging and rooted in the present moment of writing. As a result of these differences in content, it is very possible that a person's Tumblr habits may diverge widely from their other social media endeavors. Since the Facebook profile is likely to be viewed by family or even potential employers, it often becomes heavily edited and modulated public face, attached to a known person.

Meanwhile, that same user's Tumblr is more likely to contain more candid material, such as political opinions and personal anecdotes. The users who follow particular Tumblrs are connected by interests, and are not bound by personal interactions in real life. Tumblr, for many groups, becomes a haven of curated news stories and images. One can follow specific users and tags in order to receive constantly updated streams of information. If you want to learn about subjects ranging from fitness to African-American natural haircare to vegan cooking, you can instant tailor a feed from the blogs of like-minded users. A Tumblr feed can become the magazine or newspaper which you dreamed of. Everything becomes tailored to the individual reader's interests.

For the queer community, this split between the public and private face in nothing new. Even openly queer people on Facebook may face an unspoken stigma against cluttering up straight friends or family's newsfeeds with queer content. Tumblr can fill the void and become a public manifestation of this private face. Not only can one's feed have a narrower focus, but one does

\footnotetext{
${ }^{3}$ Tumbling on success: How Tumblr's David Karp built a $£ 500$ million empire. Wired. Febuary 2, 2012. http://www.wired.co.uk/magazine/archive/2012/03/features/tumbling-on-success?page=all. Accessed on January 14, 2013.
} 
not need to justify the focus of the feed to anyone they know in real life. For the self-identified "social justice" queer community on Tumblr, this been a very active space.

\section{Finding and Defining the Queer Social Justice Community on Tumblr}

The easiest way to find anything on Tumblr is to search for keywords called "tags." Some tags which are broadly attached to the queer community on tumblr are what one would expect: "queer", "gay", "lesbian", "lgbt", "mtf" or "ftm." For the more social justice oriented section of the queer community, tags such as "radical queer", "social justice", "gender" and "sexuality." They also have a tendency to post more articles to do with queer issues, both inside and outside of the community. Tags such as "privilege", "cissexism" and other "sex positive" are also quite popular. There is no clear cut way to ring-fence this community from the rest of the queer Tumblrs. For this particular paper, I started with blogs which which referenced the scandal involving Ira Gray, a prominent self-styled activist in the community. From there, it became easy to follow a chain of reblogged posts. It is easy to dismiss this community as a "slacktivist" community which only preaches to its choir. The posts are circulated and reblogged amongst the same community, and rarely appear outside of the space. However, this Tumblr-space is an important first stop for many queer young people who are coming into their own. This is where they learn how to present themselves as queer people in a heterosexist world. Many people who are out on Tumblr are not out on any other sites, let alone in their physical surroundings. This platform is often the only place where they feel safe to disclose their sexual orientation. Tumblr is becoming a space where, increasingly, intra-queer dynamics are negotiated.

\section{Problematic Self- Identification and Privilege}

A template has developed for the queer social justice Tumblr. A typical social justice queer blog's author will introduce themselves with a descriptive list on their homepage or "about me" page. Here is an example of what one could typically find: "Sparkle-king, asexual-faggot, whiteboy dyke, 23, femmeboyant, Sagittarius, Masshole...My pronouns are varied. My gender is sometimes." ${ }^{4}$ This is a much more direct introduction than one could ever accomplish in a faceto-face meeting. The fact that some of these identities appear to conflict (i.e. "king", "dyke", "femmeboyant" "asexual") is meant to contribute to the image that a deeply original and sincere queer personality is at work. It is difficult to envisage how this person can embody all of these identities beyond the confines of the internet.

Tumblr has become a unique platform for the expression of identities which do not openly express themselves in the physical world. For example, there are large communities of "otherkin" on Tumblr. Otherkin are humans who identify as other beings, such as animals, or mythical creatures such as elves. There is also a community of "transethnic" people who claim that they were born into the wrong ethnic group. Since they are vulnerable to ridicule in the real world, most keep the disclosure of their identity to the confines of the internet. However, they are often ridiculed online. Members of more widely recognized oppressed groups, including queer and disabled people, often take umbrage at being likened to such groups: "I didn't even know Otherkin existed before Tumblr. I knew that transgender people existed, mainly because I'm constantly looking at people wondering what pronouns they would prefer. I don't look at people

\footnotetext{
${ }^{4}$ frompasttofutureme.tumblr.com Accessed January 9, 2013.
} 
in cat ears and a tail and wonder, "Oh, I wonder if they'd like a can of tuna."So, yeah. Otherkin are not oppressed, they are NOT part of the trans community or struggles, and I have never seen anyone go through surgery to become a fucking cat/horse/donkey/monkeyratdragon/whatfucking ever. ${ }^{5 "}$ As Max Read states in a Gawker post about the subject: " There's a sharp division between the activists who believe their ethical and ideological commitments require them to accept to be open to any professed identity - and those who think that in the absence of structural oppression, cisgendered white people claiming to be gay Korean cats aren't just playing fantasy games but also undermining the strength of the movement by taking it to a bizarre conclusion." ${ }^{6}$ One can see that this type of tension can occur within one group, namely the queer community.

This combination of identities is a badge of public queer authenticity. But the list also acts as an armor any potential accusations of insincerity. It also seems like an attempt to live at a cultural intersection, but without an adequate understanding of what intersectionality actually means. The identities which are constructed to conflict rather than coexist.Due to confluence of identities, many participants take pains to list what privileges and "disprivileges" they possess. The Tumblr "Fractured Refuge" states that such a list provides accountability when talking about social justice issues:

"I am white. I am allistic. (I am not autistic.) I am dyadically sexed. (I am not intersexed.) I am physically abled. (My sight, hearing and bodily systems work more or less as the medical establishment says they should.) English is my first language. I was born in the US and therefore have both Western and US'ian privilege. I am not easily marked as another religion. (An example would be, I am not Muslim, therefore I do not wear hijab and I am not a target for Islamobigotry.)

Ways in which I am disprivileged: I am queer. I am trans*. I identify as genderqueer. However, I acknowledge the immense privilege I hold as a person who still mostly conforms to the gender norms society expects of me. Because of this conformity, I am always read as a cis female which, of course, comes with its own set of disprivileges. I am poor and working-class. I am fat. I am working on loving my body. I have some pretty severe mental illnesses. I struggle with depression, PTSD, and anxiety. I am also in ongoing recovery from cutting, an eating disorder, and drug addiction. I am part of a trauma-based multiple system. This means there are multiple people inhabiting one body. They came about as a result of severe trauma I endured."7

In a shorter list of things entitled "other things worth mentioning", the writer goes onto state: "I am "smart". My IQ is well above average. I completed high school and went to college, but had to drop out due to mental illness." This person also identifies as a sex worker, kinky and a single parent.

\footnotetext{
${ }^{5}$ http://watchful-entity.tumblr.com/post/32457711618/otherkin-are-not-trans. Accessed February 16, 2013.

${ }^{6}$ From Otherkin to Transethnicity: Your Field Guide to the Weird World of Tumblr Identity Politics. Gawker. M. Read. September 6, 2012. Accessed February 7, 2013.

${ }^{7}$ fracturedrefuge.tumblr.com Accessed January 12, 2013
} 
Listing the ways one of privileged and underprivileged can act as a double-edged sword. One the one hand, the person is aware that their view on social justice issues can be colored by whatever privileges society has handed them. But on the other hand, this form of labeling attempts to rigidly quantify influences on society which act in much more fluid and insidious ways. A strange consequence of this labeling is the rush for users to self-diagnose and label what they perceive to be their own disabilities. It's not uncommon for some social justice Tumblr bloggers describe themselves as "neuro-atypical" or present some other unnamed disability. Many bloggers will name their specific disability to help others or get information. Yet supplying fuzzy descriptions of one's disability is, arguably, a tactic to curry favor with the rest of the community. It also acts as a valuable shield against criticism. More troublingly, the accompanying the list of non/dis/ under-privileges becomes a perverse trophy case.

In a reaction against mainstream 1960s America, the hippies took similar pains to become the opposite of what a staid society accepted. The more unsettled, promiscuous and unconventional you were, the more social cachet one gained amongst other hippies. Radical queer social justice circles operate in a similar way. Placing those with a disability or disadvantage on a pedestal is an attempt to right longstanding wrongs. However, due to the amorphous quality of the internet and the complexities of human nature, it becomes easy for others to take advantage of this system. Rather than outright lying, some do this through embellishing the truth about their current circumstances, possibly convincing themselves that they have less power in the world than they actually do.This brings us back to Erica, the idealistic young cyberpunk from 1993. In order to have a power in this particular space in Tumblr, she would have to do more than present herself as queer. In this space, she would have to acknowledge her white privilege as an automatic impediment to her views or fudge some other ethnic identity to gain favor. She would have to present herself as some sort of victim or survivor. She would have to claim that she was less than able, be it physically or mentally. The "imagination and curiosity" she mentioned in her speech have no currency here. The power in this community lies with those who can play the most enticing victim.

\section{Self-Care and Self-Regulation}

As a result of this sensitive environment, mechanisms have been put in place to maintain the queer Tumblr-sphere was a "safe space." The most overt of those mechanisms is the "trigger warning." Trigger warnings are tags attached to posts about may contain content which may be viscerally disturbing to some readers. For example, is a post mentions rape, the writer will append a tag saying "trigger warning: rape." Posts which reference eating disorders or other forms of self-harm will carry trigger warnings as well. In both of those cases, warnings are justified. Rape survivors would not want reminders of their experiences. People recovering from self-harming behaviours should actively avoid engaging with literature about it until they are in a stronger place.

However, the trigger warning list has expanded to include warnings for "ableism" "cissexism" "racism" "transphobia" and other similar labels. The posts themselves are not in favour of these prejudices, but seek highlight and address them. Ironically, the trigger warning can serve to deter the people who are most likely be helped by the content of the posts. When viewing the wide range of trigger warnings, one cannot help but wonder: what does it mean to be "triggered?" 
According to the Geek Feminism Wikia: "[Trigger warnings] are designed to prevent people who have an extremely strong and damaging emotional response (for example, post-traumatic flashbacks or urges to harm themselves) to certain subjects from encountering them unaware. Having these responses is called "being triggered"." 8 Incidents which occur in reality never come with red flags. But when such things are even mentioned on Tumblr, they must be tagged and quarantined from a fragile, victimised community.

Some critics of trigger warnings view them as condescending to survivors because their presence underestimates the survivor's resilience. ${ }^{9}$ But there is also strong chance that the trigger warnings are contributing to the creation of a community of victims. The presence of warnings heightens the reader's sense of threat which may even surpass the content of the posts. The trigger warning attempts to pre-empt psychic pain and act in a parallel fashion as Post Traumatic Stress Disorder briefings. After a major disaster, such as an earthquake or terrorist attack, is it customary for teams of care workers to go to the afflicted area and debrief survivors and witnesses about posttraumatic stress disorder. However, a 1996 study on PTSD debriefing showed that the intervention caused more harm than good: "... those who had been debriefed were much more likely to qualify for the diagnoses of PTSD and to express hostility, feel depressed and anxious, and report a lower quality of life than those who received no help. The conclusion was that the early interventions were actually impeding the mind's natural healing process." ${ }^{10}$ The trigger warnings, in their attempt to shield the community are more likely to increase feelings of fear and victimisation. This is not to say that they will induce a full-blown textbook case of PTSD, but it can heighten the sense of victimisation. Warning people of potential trauma is a selffulfilling promise of trauma.

The attempts to create a utopian safe space are actually creating a community of entitled victims. Yet this environment helps sustain the community. The users keep returning to air grievances and seek authenticity. One of the more popular tags in this community is "self-care." The phrase "self-care" derives a quote attributed to the African-American lesbian poet Audre Lorde: "Caring for myself is not self-indulgence, it is self-preservation, and that is an act of political warfare." However, on Tumblr, this act of "political warfare" manifests itself as semi-nude camera-phone pictures of the users followed by captions about accepting one's self as beautiful. Pictures of over-indulgent foods, such as cupcakes, are also popular forms of self-care.

Another popular form of "self-care" is femme-flagging, a practice which seeks to replicate the hanky-code via nail-polish for femme- identified queers. The femme-flagging tag on Tumblr is full of pictures people displaying their manicures. Femme-flagging has yet to properly codified and is usually made up by the user as they go along. One user notably painted a middle-finger a glittery green shade, which was meant to say "fuck capitalism." Unless this user has discovered a way to brew nail polish at home, this is a rather ironic choice.

\footnotetext{
${ }^{8}$ Trigger Warning. Geek Feminism Wikia. http://geekfeminism.wikia.com/wiki/Trigger_warning Accessed on January 162013.

9 The Awl. When "Trigger Warning" Lost All It's Meaning. C Sicha. May 30, 2012. Accessed January 16, 2013.

${ }^{10}$ E. Watters. Crazy Like Us. (New York, 2010) pp 117-119.
} 
Seeing the labelling and commodification of identities on Tumblr brings to mind Carmen Hermosillo's seminal essay "Pandora's Vox: On Community in Cyberspace." ${ }^{11}$ In this essay, Hermosillo argues that cyberspace has does not provide a place which is free of hierarchies and biases. In fact, the virtual world can serve to calcify these prejudices:

"I have seen many people spill their guts on-line, and I did so myself until, at last, I began to see that I had commodified myself... I created my interior thoughts as a means of production for the corporation that owned the board I was posting to, and that commodity was being sold to other commodity/consumer entities as entertainment. That means that I sold my soul like a tennis shoe and I derived no profit from the sale of my soul... (Hermosillo, 1994)

Not only do emotions become commodified as entertainment, but they can lead the user into believing that they have something of substance to gain from "spilling their guts." This space becomes self-regulating, but in a manner which feeds off of its members, rather than nourishing them. One frequent poster, a queer person with a mental illness, posted that they were being prescribed new psychiatric medication, and wanted other users to check on zim if ze didn't post. Upon returning to the blog after two weeks, the first thing this person wrote was: "I'm here. I'm alive. I'm not okay. Thanks for not asking." Ze then went on to reblog a cartoon advocating openly asking people about their mental health. Underneath, Ze wrote, "Relevant. Hint fucking hint." This person later wrote "Thanks for abandoning me. I needed that." The frustrated passiveaggressive tone of these posts is unnerving because of the desperately needy quality. For this person, having their absence online go unremarked appears to be as hurtful as having their absence from a family home go unnoticed. With so many false devices for safety in the community, it is easy to see how more vulnerable users may lose sight of the fact that they are just another relatively faceless user among hundreds which their fellow users follow.

\section{Fuck the Patriarchy: A Quick Study of Sexual Victimhood on Tumblr}

While researching for this paper, I stumbled on a femme-flagging post which caught my attention. It was by a user called Claire. Claire describes herself as a "Queer, fat, femme line cook from Milwaukee, WI." Her pattern of nail-polish meant "anger towards the patriarchy and our rape culture", and it in response to a sexual assault she had been subjected to in the previous weekend. I went to her original site and found an account of the assault, complete with a trigger warning:

'On Sunday night I was at a small party at my gentleman friend's house. It was getting late and we were both pretty drunk, but we still managed to sneak off and have sex. Afterward, I was gathering my stuff in the kitchen to leave and he was falling asleep on the couch. One of the other guys at the party, I think one of his roommates (I hadn't really been introduced to him), cornered me in the kitchen and tried to shove his hand up my skirt. I told him no and had to physically remove his hand. Then I tried to wake up my guy friend, but he was too drunk and was completely out. So I grabbed my bag and as

\footnotetext{
11 "Introducing Humdog: Pandora's Vox Redux." http://folksonomy.co/?permalink=2299. Accessed February 6, 2013.
} 
I tried to figure out the lock on their door so I could leave, the roommate kept trying to kiss me. After I said no two or three more times, he finally opened the door for me so I could leave. I had to walk to my car in the early morning daylight in a little dress, sobbing my makeup off and generally just looking like a mess. I am so shaken and upset. I admitted to my boss what happened and he covered my shifts for yesterday and today.

Despite the fact that everybody has been yelling at me to do so, I have no desire to call the cops. I do not trust cops. At all. My gentleman friend does not have his green card and I don't want to create problems for him or any of the other guys in the house whose immigration statuses I'm not sure about.

There are other major reasons, too, but those are just too personal to get into here and I'd rather keep them to myself'.

There is no doubt that this should not have happened to her. It was a sexual threat and an infringement on personal space. However, it is arguable that Claire had narrowly avoided being a victim of sexual assault in this case. But she presents this as a sexual assault, and presents herself as a victim of a sexual assault. In addition to being a victim, Claire also manages to represent herself as a good guy for not calling the police due to the perpetrator's immigration status. Without explicitly stating so, we learn that the aggressor was some kind of foreign "other." This appears to be a conscious inversion of the popular American "white female in distress" trope. She retains the martyrdom of the trope, but with a modern twist: she's caught up on her politics enough not to go running to the police. The themes of this post (white femininity in distress, ambiguous accounts of assault, and the foreign attacker who needs to be shielded from the authorities) recur again in story of Ira Gray.

\section{Queer Theory and Utter Honesty}

Ira Dalton Gray is a transman in his early twenties. Originally from California, Ira claims on his Tumblr site that he was kicked out of his home by his devoutly religious Messianic Jewish parents. He was then betrayed by girlfriend who had promised to take him in. He spent a long time couch-surfing until he was finally taken in by a sympathetic couple. He devotes much of his time to activism, working with queer youth, and dispensing advice over the internet. At the time the scandal broke, he was living in the Phoenix, Arizona area.

The overall tone of Ira Gray's story is of a person constantly under attack from a young age. Unlike many autobiographic narratives of triumph over adversity, Gray's story is a completely humorless account of repeated victimization, committed by various people in his life:

The first time I was called a dyke was by my sister while we were changing into our gis for our after-school Chinese Kenpo lesson. To her, it was just a word, but I will never forget it. From then on, it seemingly never stopped. My mother singled me out repeatedly. I sometimes wouldn't be allowed in the arcade. I was told to sit like a girl at the table. I was not allowed to hang out with girls who were too masculine or boys that were too feminine. When I got old enough to use a computer. My parents would search it 
along with my physical belongings like I mentioned earlier. Anything to keep me from potentially being queer; she protected me as if I were being personally hunted. I was indoctrinated into an adamant hetero/cis-sexist. I played the part well.

He paints a one-dimensional portrait of his life, a life which was apparently a constant struggle against a cruel cissexist world. The key antagonists in the world were his parents. However, Young Ira knew how to play the game. Gray paints himself as a sort of deviant prodigy who has faced nothing but obstacles.:

Don't be gay, and go to college. While that's certainly not the exact way my parents said it, that was all they cared about. As a three-year-old, I would receive this lesson for the first time. I had several boyfriends and hung out with older youth so as to gain a one-up on the educational system. I had my first kiss, taught myself to read, and spent much of my time correcting people - a habit I still have.

After escaping his stifling and cissexist homelife, Ira Gray made a name for himself in queer activist circles. Ira Gray's view of queerness manages to be sprawling yet parochial. For example, he made a video called "I only date cis-girls and FTMs." ${ }^{12}$ This video provides an example of how Gray's logic, flawed as it is, managed to become so popular. The eight-minute video was in response to a friend of his who stated that his preferred dating pool consisted of ciswomen and FTM transmen. Gray took offense to this. "In order to justify that logic, one must use really cissexist forms of thinking..." he says. "Like trans guys are inherently feminine because of our gender designation at birth. Or transwomen are inherently masculine... or that transguys are the 'best of both worlds...To my lovely female-identified allies, mostly those who identify as queer.... refusing to date transwomen but being $\mathrm{OK}$ with transmen and being OK with cis-gender women is super, super cis-sexist....I can't tell you what to like and what not to like, but I can implore you to question why you like those things in the first place." 'Yet later in the video he says, "Go for [whatever you like] but don't let gender freak you out."

Unfortunately, in Ira Gray's rubric, gender is something to become freaked out about. If you are solely physically attracted to people with vaginas or those who have been socialized in a particular way, then stating so automatically makes you cis-sexist. What he is advocating is known in queer online circles as the Cotton Ceiling argument, which states that queer cis-people who do not sleep with trans-people do so out of deeply embedded cis-sexism. One of the main problems with his manifestation of this argument is that it naively assumes that being open to sleeping with members of certain groups is a sign of respect towards that group. (If this were the case, domestic violence would not exist.) All his application of the Cotton Ceiling argument seeks to do is further police inter-queer relationships in an unnatural way, by creating an obligation which does not do either party any good.

The person who he is criticizing in this video is not refusing to sleep with cis-people or transpeople, just not all of the cis-people and trans-people. The stated preferences for cis-women and trans-men makes Gray insecure with with is own masculinity. His chagrin at being placed in this

\footnotetext{
${ }^{12}$ http://www.youtube.com/watch?v=ZNH502yUU74\&list=UUGTKBrmz-tBRfWn23t867MQ\&index=2 Accessed January 1, 2013
} 
category alongside women is, ironically, quite misogynistic. He conveniently overlooks the fact that there are transmen who view other transmen and cis-women to be their dating pool. It is also notable that he does not criticize his friend for leaving out cis-men.

Gray also equates a sexual preference for certain groups as an automatic insult to other groups. This creates a hierarchy of political correctness. At the top of the hierarchy is an ideal of wellrounded pansexuality which rarely occurs in nature. It does not allow for the lopsided ambiguities which queerness often yields. Tellingly, this identity hierarchy panders to the way much of the online queer social justice community represents itself. Ira Gray then goes on to equate physical characteristics as being fairly arbitrary markers on a birth certificate. "It's like saying you're only attracted to whose names start with the letter A!" he laughs. This flippancy about gender identity undermines the struggle of transpeople (including himself). It also undermines the struggles of queer people who already have difficulties stating their preferences in a heterosexist world. It is also unfortunate that, despite the many serious issues transpeople across the world face, he choose to make speak on a topic which would only be a concern to middle-class queers with time to in-fight about such things on the internet.

Despite the obvious holes and contradictions in his argument, many of his readers would have bought into it. One reason is because most of them are young queer people who are still finding their way. He is able to use terms culled from queer texts which make him sound authoritative. His audience would still be learning how these terms relate to them, and would not have learned how to approach them critically. Ira Gray was a charismatic figure on Tumblr. His posts were widely circulated over the ftm (female-to-male) and transgender threads. It is interesting to note that Gray rarely reblogged posts from other users. Most of his posts contained original material, which is somewhat usual for Tumblr. His blog had also been running since autumn 2009, which is a long time for an online presence. In the header of his blog, he writes: "What sets this blog apart from the rest of the transition blogs? Queer theory and utter honesty."He was considered an authority. He could give decisive (and often simplified) statements in response to questions. He could also be contradictory and somewhat capricious. In spite of his hatred of being seen as feminine, he wrote a poem calling for a "femme masculinity." In spite of his chosen last name, Gray was most comfortable with definitive answers. At the height of his celebrity, he had written an article in The Huffington Post. ${ }^{13}$ He had also bumped into one of his fans IRL (in real life), who exclaimed, "I can't believe I'm meeting you!" He also was sent a free soft pack to review from another website. In the small arena of queer Tumblr celebrities, Ira was Michael Jordan. His commenters fawned over him. They marveled at his bravery in the face of such hostility, his perceived grasp of queer issues and tireless activism. But the facade was coming undone.

\section{Rape Accusations and "Chronological Lying"}

The catalyst for the abuse accusations is not entirely clear. One possible candidate was an April 5th 2012 post entitled "I Badly Need to Get This Off My Chest." Ira wrote about about a sexual encounter he'd had with a cis-man. Despite the fact they discussed their boundaries in advances, Ira was left feeling uncomfortable. When Ira didn't want to have sex again, the man respected

\footnotetext{
${ }^{13}$ Gray, Ira. "Transgender (Mis)Education." The Huffington Post. TheHuffingtonPost.com, 28 Feb. 2012. Web. 26 Feb. 2013. <http://www.huffingtonpost.com/ira-gray/transgender-miseducation_b_1307961.html>.
} 
this, and masturbated instead. "I'm cool with someone jacking off when I don't want to have sex," he wrote. "But at the time, I felt more like he was just trying to get hard again at which point he'd wake me up or not wake me up... I don't think anything went on for the 3 hours I was asleep for, but I'm also not omniscient, which worries me." The other potential catalyst was a post made on May 162012 entitled "I've been thinking about the nature of coercion:

"...I could be wrong, but it feels like there's a distinct difference between coercion aimed towards property (forcing a building to explode for example) and the coercion of the body. For whatever reason, the latter seems to be much more acceptable with the culture at large. It's socially acceptable to pick up young children, to rape, to enforce gender norms, while it's weird to ask children what they want, to ask for consent, or to bend the rules of gender. Conversely, it's unacceptable to paint murals on abandoned walls or to steal and especially wrong if you're a person of color doing these things."

Like many of his posts, both of these received about a dozen "likes." Both posts are painfully ironic in light of the accusations which were made later. One can see how such posts would be infuriating for anyone who was a victim of his. For the purposes of this paper, it had become difficult track down the first post accusing Ira Gray of rape. Two of the accusations had been published and then deleted. Two others which were heavily circulated can still be found originating from Tumblr users queerandpheasantstranger (who now goes by wine-andmasturbation) and asvainasiallow. Queerandpheasantstranger's (who also goes by E.W.) accusation came after some deliberation. According to her, Ira had strongly hinted that he would smear her name is she mentioned that anything happened. He was aware of his power in the queer communities both online and in reality. Ira had a history of being "triggered" by being called out on his behavior, and blamed it on his unnamed mental illness. (In other words, he could be very vindictive.)

According to E.W., she was too tired to have sex with Ira and had fallen asleep: "At this point, I had been awake for 36 hours, and had been drinking. I woke up with his junk in my face, with him putting his dick into my mouth." She was startled and said "I don't want to go down on you." For Ira, the phrase "go down on you" was triggering because of it's connotations with female genitalia, and he started crying. He ended up making her apologize for being cissexist and made her feel guilty for the entire thing. Ira and E.W. had an altogether unhealthy relationship. E.W. became depressed to the point of suicidal ideation, and Ira kept control of her through inflicting cis-guilt. It appears that he could categorize any refusal of sex from a partner as a manifestation of transphobia:

"He put more energy into manipulating people into sex as he did actually using consent, and whenever he was told that I wasn't comfortable, or declined his "consent" requests, he would act sad and make it about him feeling neglected...And then he has the nerve to say "we talked" about it, or "I always checked in and asked for consent". You didn't "check in", you "checked in" frequently to see if I had changed my mind yet, you 
checked in to see if my "no" was still a "no". You wrapped it in fancy language and said "well I just wanted to check in". ${ }^{14}$

According to asvainasiallow, she had a similarly dysfunctional relationship with Ira. Instead of a drinking problem, she struggled with an eating disorder. Ira would take it personally when she did not eat something because he felt as though she was "lying to him." He also convinced her to go off of her bipolar medication, claiming that medication was just a scam by drug companies. He tried to control what she wore, claiming that shaving was just a societal expectation and that her heels were "hooker heels."

In addition to undermining her as a human being, he frequently instigated arguments with her conservative family who were allowing him to stay at their house. After he lost his job, his girlfriend was the sole financial support for both of them. She also did the majority of the housework as well, while Ira spent all day on Tumblr. The turning point came over an argument about toothpaste. Despite their straightened finances, Ira wanted her to buy an expensive vegan toothpaste. At this time, he was still eating meat occasionally, so this was a ridiculous request. At this point, she finally stood up to him and told her that she was like she was being used. But at the end of the argument, she was the one who ended up apologizing.

Also, there is this:

"There were times when in his sleep Ira would try and have sex with me. I would have to fight him off and it was almost impossible to wake him up. No matter how hard I shook him or how loud I yelled. Due to previous experiences I get frightened/triggeredby people not stopping when I tell them to. When I told Ira about what he would do in his sleep he basically told me to just let it happen because he wanted to know what it was like." ${ }^{15}$

The only thing more stunning than the accusations was the response posted by Ira Gray himself. On June 7, 2012, Ira Gray began his post is his normally careful, politically correct fashion as dictated by the community:

"So, some of you may have noticed some stuff going around Tumblr accusing me of being a rapist. I want to start this by saying there is nothing I can say or do in response to this that isn't an abuse of the access to male privilege that I have.

There's no such thing as a win for any of the parties involved in this, because it's all terrible no matter what. Lastly, I want to note that I'm also a survivor of sexual and emotional abuse. It's not like I don't know what it is to be abused in any way. I know all too well."

\footnotetext{
14 "The Sassy Androgyne From Flushing." The Sassy Androgyne From Flushing. Tumblr, 12 June 2009. Web. 26 Feb. 2013. <http://sassyandrogynefriend.tumblr.com/post/24729139653/starvedforjustice-reasons-why-i-dont-givea>.

${ }^{15}$ Asvainasiallow. "I Don't Need A Fucking Title." I Don't Need A Fucking Title. Tumblr, 25 June 2012. Web. 26 Feb. 2013. <http://asvainasiallow.tumblr.com/post/24944388358/tw-abuse-eating-disorder>.
} 
In addition to acknowledging his male privilege in order to cover his bases, Gray is leveraging a claim that he, too, is a survivor. He then proceeds to describe how he does his "best to practice good consent," through checking in with his partners before, during, and after sex. He admits that he is not good at reading hints, but will stop when confronted with a "no." He claims that he doesn't want to smear the name of the accusers, but then goes on to say that one in particular had ask him for help for a problem with "chronological lying." (One can only guess that he means "chronic" or "pathological" lying.) According to him, this person claimed that they were with him for "activist points." According to him, they had discussed what had happened between them and agreed that neither one had practiced good consent, and resulted in the both of them "feeling violated."

Gray goes onto claim he and this person had a "miscommunication", and that they had extensively discussed their respective "triggers" beforehand. He insists that he apologized afterwards: "I didn't apologize in the "Oh, I'm sorry you feel that way" sense that is really patronizing. I said "I'm sorry I violated you. ""He goes onto state the following:

"There's no such thing as $100 \%$ good consent, but that obviously doesn't mean we shouldn't be working towards it. What these allegations have done, however, is make me question what truly good consent looks like. What happens if you do everything the workshops you've attended and the reading you've done tells you to do and people still feel violated? What does it mean if you both feel shitty about what happened? The only reason I haven't is because if I say I'm not a rapist, then I'll be an apologist. If I say I'm a rapist, then I'm confessing to something that I didn't do. These people obviously feel the way that they feel, and I can't validate that while speaking up...Yes, I have messed up and will continue to do so, but at the end of the day, Tumblr culture will say that whatever I say doesn't matter. All I can do is recognise where I have done wrong, attempt to resolve things, and go from there. Yes, I will always perpetuate misogyny despite my best efforts. Said efforts don't absolve me though. I will perpetuate rape culture and have done so despite my beliefs and efforts. I don't expect or desire to be absolved of these things. I hope to learn and grow for there is always room to do so. Lastly, I've obviously hurt these people; otherwise, they wouldn't be saying these things about me. I am not a rapist though."

The final chunk of text above is disturbing on a number of levels. Gray insists that he followed a proper "checking-in" procedure, which, to a casual observer, is reminiscent of something taught in a First Aid class. Yet despite his insistence on following scrupulous ritual, Gray glibly declares that "there's no such thing as $100 \%$ good consent." In a more interesting twist, he then goes onto turn the blame onto the hyper-politically correct culture he has benefitted so much from. (It is worth noting here that Ira Gray was a quite a prolific workshop leader in his local queer youth community, and also led "consent workshops.)

The accusations and the rebuttal sent waves through the queer Tumblr community. Not only was his lack of accountability problematic, but his manner of manipulating people through the same rhetoric which catapulted him to Tumblr fame was also disturbing. Most users were quick to disown Gray, and delete any posts which they had reblogged from him in the past. Groups such as "Self Made Men" and "FTM Kickstart" released statements denouncing him. Many users 
opened up about surviving sexual and relationship abuse in the past. So users were so overwrought with emotions of betrayal that they had to take a break from Tumblr for a while. Yet the response was not unanimously against Gray. A Tumblr site called "I Stand with Ira Gray" quickly opened and just as quickly closed after a strong backlash. (Many suspect that Ira Gray himself was behind that group.) Anonymous posters posed the question "What ever happened to innocent until proven guilty?" to the accusers and the growing anti-Ira Gray faction. Many users just would not believe that any of this was possible.

There was also an recurring accusation of radio silence coming from the white transmale community. Despite the fact that many white transmen denounced Ira Gray from early on, this accusation comes with some history. Many in the community feel as though white transmen have gained too much prominence through the mechanisms of white privilege and male privilege. In fact, many feel that these mechanisms are what allowed Ira Gray to go unquestioned for so long. What makes this interesting is that Ira Gray is quite racially ambiguous. Throughout his blog he claims that his first language is Spanish and frequently identifies as a person of colour. Yet he could pass for white when necessary; he has acknowledged this. His chosen middle and surname, Dalton and Gray, are Anglo-English names.

One user responds to the question of police involvement with the following: "Who the fuck are the proper authorities for queer people and transpeople?... Do you honestly expect us/them to trust the criminal justice system-- a system which criminalized trans bodies and bodies of colour... how obtuse do you think we are?" Other users had similar responses, claiming that they did not want to send another man of color or queer person through the American penal system. In this context, Ira Gray could also pass for a person of colour.

Rather than advocating that Ira Gray face prosecution, the community preferred to denounce him within the confines of Tumblr Court. On one level, this makes sense. Tumblr was such an important part of his life that taking it is away would damage his ego. Yet hiding behind the "queer man of color" excuse obscures the other, less palatable reasons for not wanting to pursue legal action. Courts are notoriously bad at putting rapists behind bars. The nature of Gray's crimes, which were all in the context of relationships, would be particularly difficult to prosecute. There is also the fact that the accusers did not want it to go to court. Despite the fact that they invoked a potential felony charge, they did not want to take this to the courts. However, they were keen to get Ira Gray to stop doing activism work in the real world as well as online. E.W. wrote an open letter making her demands clear:

— resign from any positions of power you hold. that includes... positions that include you working with people who do not have access to male privilege.

- take down your blog, your youtube channel, and any other "educational" platforms you may manage. never again give a workshop, run or organize a lecture, accept a speaking position, or ever spout your brand of "activism" before another human being. explicitly renounce your role as an educator. do not ever again refer to yourself as an activist, a role model, a teacher, an example, or an ally (even aspiring). ${ }^{16}$

\footnotetext{
${ }^{16}$ http://cisnormativity.tumblr.com/post/25020031197/an-open-letter-to-ira-gray
} 
Other demands on that list included writing an open letter of apology admitting that he was a serial rapist and shutting down his website. The website's domain was allowed to expire in December 2012. It was silent and inactive after the rape allegations. He is, however, still active in local queer groups and youth groups. He now operates under the name Ira Bohm-Sanchez. In February 2013, he was awarded a \$10,000 scholarship for his queer activism work.

\section{Conclusion: Beheading Holofernes?}

One of the most stunning set of remarks came from people who expressed their relief that people finally saw through him, and that it showed "he didn't walk on water." It seems there was a silent community of Ira Gray-dissenters before the scandal hit. But despite the supposed "freedom" of the internet, they could only quietly disagree from behind their screens, but not say anything for fear of rocking the boat. This silence is where the resemblance to Synergia is most telling. In both the hippie commune and the queer online community, participants formed a group in order to create a haven from the cruel and hypocritical mainstream. Both communities, for a while, proudly held themselves to be freer than the outside world. Eventually, the hippie movement collapsed. One can hope that the online queer Tumblr community will have learned some lessons from the Ira Gray incident. While researching this paper, I came across Ira Gray's (or rather, Ira Bohm Sanchez's) facebook page. The header picture for the page is from the painting "Judith Beheading Holofernes" by Artemisia Gentileschi. In a facebook post a friend asked him if this was the painting he had been talking about in a previous conversation. Ira responds:

"Yes! It's my favorite painting. Gentileschi painted it while she was taking part in trial in Rome because she had been raped by a guy named Tassi who had a long history of abusing women. The trial of course was filled with victim-blaming, but he was found guilty and was exiled from Rome. He ended up back in the city 4 months later though due to connections he had. Anyway, the theory is that she painted this to let out some of her feelings of her struggle'.

It is hard to tell whether using the painting is meant as a dig at his accusers or if Gray genuinely identifies with the painting. Has he accepted his place as a now headless Holofernes, or does his still see himself as a triumphant Judith? It is easy to see how he would identify with the latter. In the shifting world of Tumblr politics, it is easy to always make oneself the victim. For Ira Gray the rape accusations were just another one of the many trials he would have to undergo to make him the ultimate queer martyr. 


\section{References}

E. Watters. Crazy Like Us. (New York, 2010) pp 117-119.

\section{Video Sources}

"Max Mouse Part 1 (2of3)." Youtube. http://www.youtube.com/watch?v=gRzPWCJqEVY

The Use and Abuse of Vegetational Concepts: Ecology, Technology, and Society-All Watched Over by Machines of Loving Grace. Dir. Adam Curtis. N.p., n.d. Web.

\section{Articles}

The Awl. When "Trigger Warning" Lost All It's Meaning. C Sicha. May 30, 2012. Accessed January 16, 2013.

"Introducing Humdog: Pandora's Vox Redux." http://folksonomy.co/?permalink=2299. Accessed February 6, 2013.

Tumbling on success: How Tumblr's David Karp built a $£ 500$ million empire. Wired. Febuary 2, 2012. http://www.wired.co.uk/magazine/archive/2012/03/features/tumbling-on-

success?page=all. Accessed on January 14, 2013.

frompasttofutureme.tumblr.com Accessed January 9, 2013.

http://watchful-entity.tumblr.com/post/32457711618/otherkin-are-not-trans. Accessed February $16,2013$.

From Otherkin to Transethnicity: Your Field Guide to the Weird World of Tumblr Identity Politics. Gawker. M. Read. September 6, 2012. <http://gawker.com/5940947/from-otherkin-totransethnicity-your-field-guide-to-the-weird-world-of-tumblr-identity-politics $>$ Accessed February 7, 2013.

Trigger Warning. Geek Feminism Wikia. http://geekfeminism.wikia.com/wiki/Trigger_warning Accessed on January 162013.

\section{$\underline{\text { Tumblr Resources }}$}

From Past to Future Me. frompasttofutureme.tumblr.com Accessed January 9, 2013.

Asvainasiallow. "I Don't Need A Fucking Title." I Don't Need A Fucking Title. Tumblr, 25 June 2012. Web. 26 Feb. 2013. <http://asvainasiallow.tumblr.com/post/24944388358/tw-abuseeating-disorder>.

"The Sassy Androgyne From Flushing." The Sassy Androgyne From Flushing. Tumblr, 12 June 2009. Web. 26 Feb. 2013.

$<$ http://sassyandrogynefriend.tumblr.com/post/24729139653/starvedforjustice-reasons-why-idont-give-a . 